\title{
Editorial
}

\section{Our Interconnection through Mobility Facilitates the Spread of Infectious Pathogens}

\author{
Chengjun Sun, PhD* \\ School of Management and Economics, Kunming University of Science and Technology, 253, Xuefu Road, Kunming, Yunnan 650093, China \\ "Corresponding author \\ Chengjun Sun, PhD \\ Assistant Professor, School of Management and Economics, Kunming University of Science and Technology, 253 Xuefu Road, Kunming, Yunnan 650093, China \\ E-mail: cjunsun@gmail.com
}

Article information

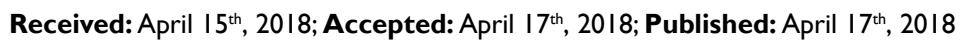

\section{Cite this article}

Sun C. Our interconnection through mobility facilitates the spread of infectious pathogens. Public Health Open J. 20I8; 3(I): el-e2. doi: I0.17I40/PHOJ-3-e005

$\mathrm{P}$ athogens have been moving around for a while. The History of the Peloponnesian War, written by Thucydides (c. 460 BC - c. 395 $\mathrm{BC}$ ), an Athenian historian, describes the plague of Athens of 430 $\mathrm{BC}$, and it is said "It first began in the parts of Ethiopia above Egypt, and thence descended into Egypt and Libya and into most of the [Persian] King's country. Suddenly falling upon Athens, it first attacked the population in Piraeus [..] and afterwards appeared in the upper city, when the deaths became much more frequent. ${ }^{1}$

The International Organization for Migration (IOM) estimates that there are more than 244 million migrants around the world today, $3.3 \%$ of the world's population. And around $60 \%$ of these migrants live in developed countries. For instance, from 1980 to 2016, there were 7.7 million new Permanent Residents of Canada. ${ }^{2,3}$ There are 60 million overseas Chinese around the world on December 31 ${ }^{\text {st }}, 2015$ according to the Annual Report on Chinese International Migration. ${ }^{4}$ Finally, refugees constitute an important factor in international migration, particularly relevant in the context of public health as they represent populations often in precarious health conditions. United Nations High Commissioner for Refugees (UNHCR) estimates at the end of 2016 that there were 65.6 million forcibly displaced worldwide people, 22.5 million refugees, and 2.8 million asylum-seekers. ${ }^{5}$

Pathogen spread has evolved with mobility. Indeed, whatever the modalities and characteristics of mobility, migrants or travelers may carry with them their latent or active infections (tuberculosis (TB), influenza, human immunodeficiency virus (HIV)). In ancient times, human pathogens followed trade routes. For instance, the Black Death followed the Silk Road into Europe from Central Asia. ${ }^{6}$ With the acceleration and globalization of mobility, things change in the advent of high-speed train and airplane; see Figure $1^{7}$ and Figure 2, respectively. Thus, as the way humans utilize space evolves, so does the spread of pathogens they carry. For instance, the severe acute respiratory syndrome (SARS) propagat- ed worldwide in 2002-2003. Although it caused only 8273 cases in 28 countries, SARS illustrated the capacity for interconnection via modern transportation methods to facilitate the rapid and global spread of an infectious pathogen. The 2009 swine flu, recognized in the state Veracruz, Mexico was transmitted to all continents except for Antarctica and the Arctic through air travel.

Border screening should be implemented on travelers leaving and/or arriving to avoid the spatio-temporal spread of pathogens of humans. And expertise in clinical medicine and public health with big data analytics and visualization should be integrated to help decision-makers prepare for and respond to infectious diseases.

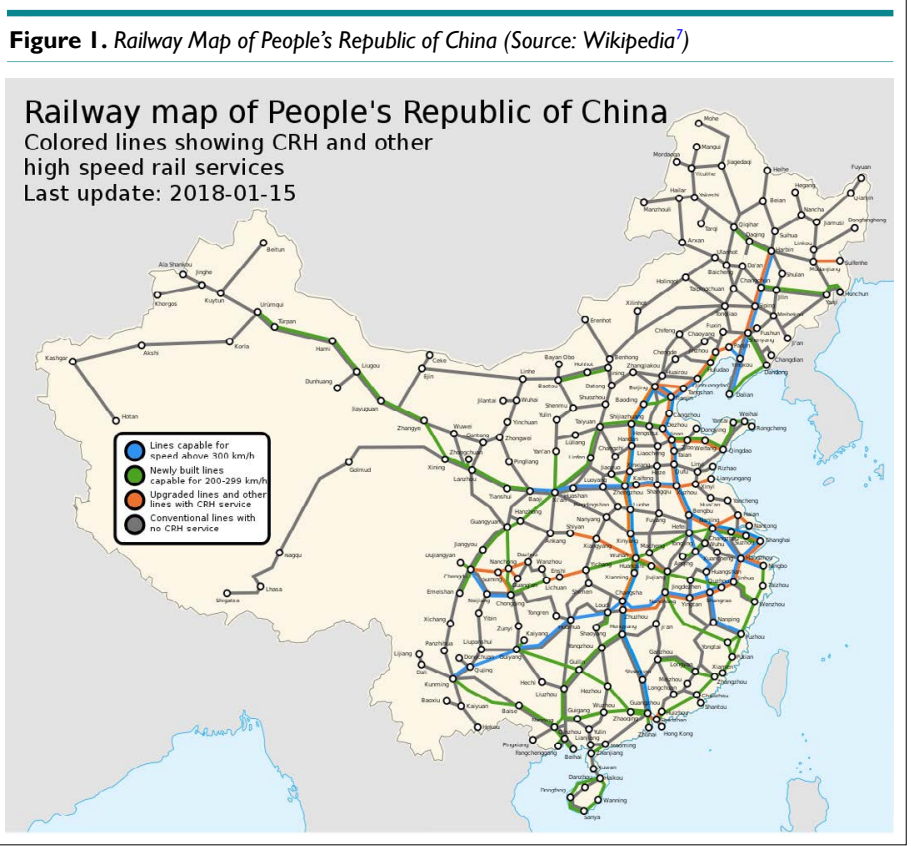




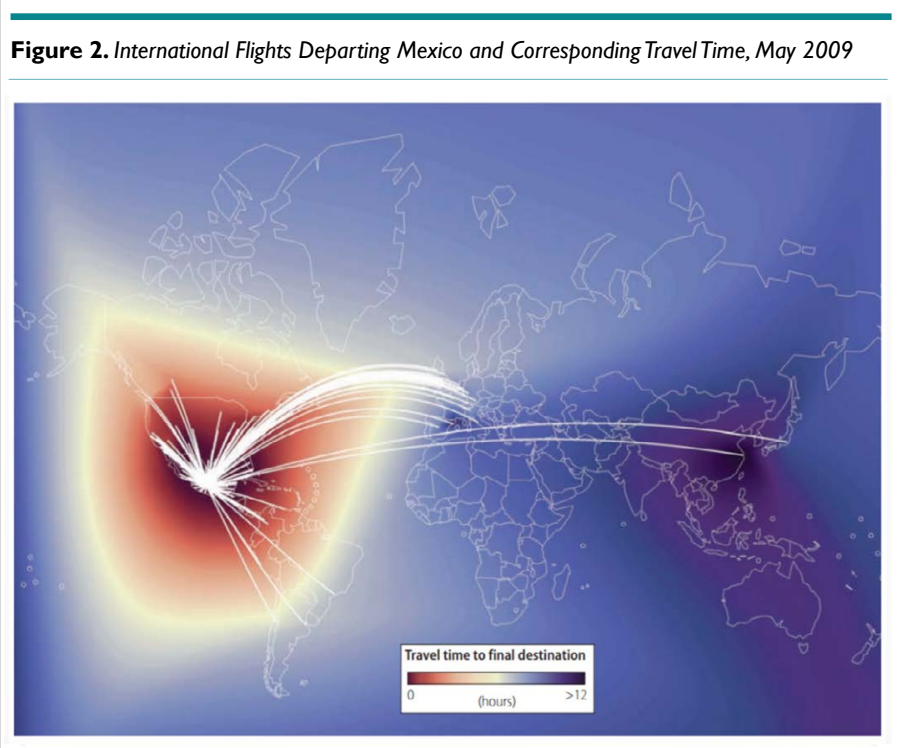

\section{ACKNOWLEDGEMENT |}

The author acknowledges financial support from the project of KMUST for Fostering Talents in provincial level (KKSY201 608050) and the project of Yunnan Education Department (2016ZZX055). The author would like to acknowledgement Kunming University of Science and Technology research facility and support.

\section{REFERENCES}

1. Wikipedia. Web site. https://en.wikipedia.org/wiki/Plague_of_ Athens. Accessed April 14, 2018.

2. Government of Canada. Facts \& figures 2015: Immigration overview - permanent residents, 2015. Web site. http:/ /open.canada.ca/data/en/dataset/2fbb56bd-eae7- 4582-af7d-a197d185fc93. Accessed April 14, 2018.

3. Government of Canada. 2017 Annual Report to Parliament on Immigration, 2017. Web site. https://www.canada.ca/en/immigration-refugees-citizenship/corporate/publications-manuals/ annual-report-parliament-immigration-2017.html. Accessed April 14, 2018.

4. International Organization for Migration. 2018. Web site. https://www.iom.int/countries/china. Accessed April 14, 2018.

5. UNHCR. Global Trends - Forced Displacement in 2016. Web site. http://www.unhcr.org/globaltrends2016/. Accessed April 14, 2018.

6. Benedictow OJ. The Black Death, 1346-1353: The Complete History. Woodbridge, UK: Boydell \& Brewer; 2004.

7. Wikipedia. Web site. https://en.wikipedia.org/wiki/Rail_transport_in_China. Accessed April 14, 2018. 